\title{
Etikk i praksis gjennom 10 år [2007-2017] 10 years of Nordic applied ethics
}

\author{
Allen Alvarez, Siri Granum Carson \& May Thorseth
}

Det er ti år siden den første utgaven av Etikk i praksis - Nordic Journal of Applied Ethics kom ut, og vi markerer jubileet med en rik og mangfoldig utgave av tidsskriftet som er egnet til a vise hvor vi står i dag. I den første utgaven skriver de davorende redaktørene at "Etikk i praksis har som mål å gjøre den anvendte etikken $i$ Norden sterkere og synligere.»Vi, de nåvarende redaktørene, vil hevde at tidsskriftet har lykkes med dette. Gjennom 10 år, 21 utgaver og 122 artikler, har vi publisert artikler om et bredt tilfang av temaer innen bioetikk, profesjonsetikk, noeringslivsetikk, forskningsetikk, idrett, teknologietikk, migrasjon, matetikk, rettferdighet og en rekke andre retninger innen anvendt etikk. Gjennom årene har Etikk i praksis utvidet både sitt repertoar og sitt nedslagsfelt. For eksempel ble en av våre artikler, Ole Martin Moens "The ethics of pedophilia" (1/2015) nylig oversatt til kinesisk. I den forste utgaven fra 2007 var alle seks artikler av nordisk opprinnelse, og den nordiske konteksten var også tematisk sentral. Ti år senere er fortsatt hovedvekten av artikler skrevet av nordiske forfattere. Andre deler av verden har imidlertid meldt seg på $i$ diskusjonen - $i$ denne utgaven finner vi artikler fra både ØstEuropa og Sør-Afrika. Tematisk ser vi en tilsvarende utvidelse - mens tre artikler $i$ denne utgaven tar utgangspunkt i en nordisk kontekst, omhandler tre av artiklene globale spørsmål.

\begin{abstract}
Aims
Ten years ago, the founding editors of the Etikk i praksis - Nordic Journal of Applied Ethics articulated the goal of the journal to contribute to the development of applied ethics by creating an arena where the field's identity can be tested and shaped (Myskja, Nydal and Solberg 2007:3). The complexity of new situations that we as human society have faced in the past ten years - brought about by social, political and technological changes in the world and in the Nordic region - called for greater ethical reflection. We need to continue to think hard and deeply to identify what is normatively at stake (articulate) and how best to handle the normative issues (evaluate) (Myskja, Nydal and Solberg 2007: 3-4). The aim is to arrive at an understanding of what good practice means to specific situations within specialized disciplines in modern society.
\end{abstract}

\section{Method}

How did contributing authors and editors of Etikk i praksis - Nordic Journal of Applied Ethics strive to accomplish this aim? No specific method or approach to ethics has been explicitly favoured. The term 'applied ethics' that identifies this journal does not necessarily give primacy to the deductivist application of ethical theories to specific situations in the articles that have been published since November 2007. Nor do mid-level principles, such as 
beneficence, nonmaleficence, autonomy and justice, have the guiding power in deciding what good practice means. As Myskja, Nydal and Solberg (2007:5) predicted ten years ago, the approach of ethical reflection tends to go in the opposite direction, i.e. toward specific questions that illuminate ethical theorizing. Issues about methodology in applied ethics will be explored in detail in the upcoming Special Issue on Methods to be published in 2018 at the beginning of the journal's second decade.

\section{Open access, open source and the OJS}

Etikk $i$ praksis has been an open access journal since 2010. As argued elsewhere by Michael Parker (2013), "those who work in ethics have a strong interest in supporting moves towards more open publishing approaches", because such approaches "have the potential both to inform and promote richer and more diverse forms of public deliberation and to be enriched by them". To enhance the journal's capacity to fulfil this aim, the journal has joined the open source community of journals that publish via the Open Journal Systems (OJS) online platform. Since 7 November 2014, the journal has been publishing articles using OJS and is hosted by the NTNU Library in Trondheim.

\section{Contributions to this anniversary issue}

The editors of Etikk i praksis are pleased to introduce six papers in this open-themed issue on the occasion of the journal's $10^{\text {th }}$ year anniversary.

In the first article, "Etiske utfordringer med nyere reproduksjonsteknologi" (Ethical challenges with newer reproductive technology), Bjørn Hofmann takes current possibilities of reproductive technology as his point of departure, and gives an overview of the moral questions it raises concerning regulations, priorities and practices. Hofmann argues that we are less well equipped for ethical reflection than we are for technological innovation, and discusses why it is so hard to arrive at stable and well-founded answers to the questions raised by reproductive technology.

Karl Persson de Fine Licht in "Hostile Urban Architecture: A Critical Discussion of the Seemingly Offensive Art of Keeping People Away" argues that defensive architectural measures designed to exclude unwanted groups of people from certain locations - e.g. benches that cannot be slept on, spikes in the ground that cannot be stood on, pieces of metal that hinder one's ability to skateboard - lead to suffering, are disrespectful, and violate people's rights. The article discusses reasons to be critical of defensive architecture and points to the need for missing empirical information to be further investigated.

In "The Distant Moral Agent", Tom Andreassen takes his point of departure in the debate on how to deal with problems occurring far away from home. The argument is partly based on Singer's cosmopolitan model of an expanding circle of moral concern, but also diverges from it in pointing to a need for a complementary tool. The author argues for revising Singer's model, adapting it into a rights-based approach for allocating duties. The aim is to identify agents who have duties towards people in need and far away. The author thereby changes the focus from the moral agent to the holder of legitimate moral claims, and he is more concerned with claims of those harmed than with duties of individuals or institutions on a global scale.

Uchenna Okeja reflects on ethical issues of expatriate employment in "The moral challenge of expatriate employment in developing countries". Okeja locates the moral wrong in the failure to respect the universal moral equality of people and in particular, the moral problem 
of expatriate employment in developing countries that involves unequal or arbitrary distribution of power among employees. The author also examines four arguments against expatriate employment that he demonstrates to be insufficient accounts for the moral impropriety of expatriate employment in developing countries. These insufficient accounts argue that expatriate employment in developing countries 1) entrenches the injustice of wage discrimination, 2) produces undesirable outcomes, 3) disregards contextual aspirations and historical memory and that it 4) is a tool of external domination and control.

In "The Concept of a European Public Sphere within European Public Discourse", Sanja Ivic analyses the concept of a 'European public sphere', in particular the European Communication Strategy for creating an active European citizenship. The aim is to demonstrate a dialectic relation between European values, identity and public sphere. The author analyses The European commission's Plan D for Democracy, Dialogue and Debate, which was aimed at organising national debates on the future of Europe. Ivic concludes that the plan was flawed, mainly due to homogeneous and static concepts of the public sphere and European values, resulting in deliberations turning into to a mere debate.

Lastly, in "Hvilke moralske utfordringer opplever politistudenter i praksisåret? " (What moral challenges do police students experience during their practical training year?), Jens Erik Paulsen and Lisa Maria Enoksen discuss challenges encountered by students at the Norwegian Police University College during their final practical training year. The authors base their analysis on exam assignments of students in their final year at the academy. The authors found that the students do not seem to be sufficiently prepared for the practical training year, and point to a need for a more casuistic approach in their theoretical training. The authors found a certain tension between loyalty and maturity on the one hand, and critical attitude and uncertainty on the other. They conclude that there is a need for a safe atmosphere in order to effectively discuss both technical/tactical issues as well as judgment and moral aspects of the challenges that students face.

\section{Meeting place for growing interdisciplinarity and diversity}

As evident in the diversity of articles published in this 10 year anniversary issue, Etikk $i$ praksis has gone a long way in nurturing collaborative undertakings between researchers coming from different disciplines. The same is true with collaboration between researchers who come from different geographical places (e.g. Europe and Africa) and cultures (e.g. Scandinavian and Southeast Asian) around the world. The collaboration that allowed the publication of Special Issues involving social scientists, philosophers, and other specialized professions embodies the continuing quest for understanding between different disciplines, as well as between people with different languages and cultures who wish to understand each other. Interpretation and knowledge translation have occurred both literally and figuratively, and further collaboration seems to have been inspired by the preceding successes of goodwill and kind efforts to understand different and closely related languages. The legacy of Scandinavian semi-communication between Norwegian, Swedish and Danish speakers inspired an article about the possibility of intentional semi-communication for fostering solidarity between members of multi-cultural society (Lasquety-Reyes \& Alvarez 2015). The same legacy has been used to inspire the call for interdisciplinarity in applied ethics when Etikk i praksis was launched ten years ago (Myskja, Nydal and Solberg 2007:3). We continue to face complicated problems in the wake of global threats, such as climate change and geopolitical conflicts, that require diverse perspectives. No single expert or perspective can provide one grand solution to complex problems. One could say that the field of applied 
ethics is represented by the ethicist's role as an embedded expert who helps articulate the relevant values and deepen understanding of the key issues. All stakeholders, including scientists and citizens, work with these values and issues to collaboratively develop solutions. The current editors of the journal continue to share the same hope that we provide a meeting place for needed interdisciplinary collaboration to flourish, today and in the coming decades. Diversity in this sense is our strength.

\section{Acknowledgments}

We would like to thank the past Editors, Guest editors and members of the Board of Editors of Etikk i praksis - Nordic Journal of Applied Ethics for the way they have shared their time and talents in nurturing this journal from the very beginning since 2007 . We are especially thankful to all the anonymous reviewers for sharing their expertise in reading and evaluating papers. No journal can exist and publish quality papers without the invaluable contribution of expert peers who review submissions to the journal. Finally, we thank all the contributing authors for their interesting and thought-provoking submissions.

\section{References}

Lasquety-Reyes, J., \& Alvarez, A. (2015). Ethics and collective identity building: Scandinavian semicommunication and the possibilities of Philippine ethics. Etikk i Praksis - Nordic Journal of Applied Ethics, 9(2), 71-87. http://dx.doi.org/10.5324/eip.v9i2.1866

Myskja, B., Nydal, R., \& Solberg, B. (2007). Leder. Etikk i Praksis - Nordic Journal of Applied Ethics, 1(1), 3-9. http://dx.doi.org/10.5324/eip.v1i1.1679

Parker, M. (2013). The ethics of open access publishing. BMC medical ethics, 14(1), 16. https://doi.org/10.1186/1472-6939-14-16 